\title{
Peningkatan Fasilitas Musala Al Anwar Untuk Mengadakan Kegiatan Salat Jumat Sesuai Protokol Kesehatan Covid-19
}

\author{
Guntur Nugroho1, Seplika Yadi², \\ 1, 2. Jurusan Teknik Sipil, Fakultas Teknik,Universitas Muhammadiyah Yogyakarta \\ Jl. Brawijaya, Kasihan, Bantul Yogyakarta 55183 \\ Email guntur.nugroho@umy.ac.id \\ DOI: $10.18196 / \mathrm{ppm} .36 .321$
}

\begin{abstract}
Abstrak
Musala Al Anwar adalah salah satu musala di Dusun Sawahan, Pendowoharjo, Sewon, Bantul, DIY. Akibat adanya pandemi Covid 19, pelaksanaan kegiatan salat di musala Al Anwar menggunakan jarak saf minimal 1 meter sebagai perotokoler antisipasi penyebaran virus Corona. Hal tersebut menjadikan kapasitas jamaah yang ditampung bangunan musala menjadi berkurang. Sejak berdirinya musala ini, kegiatan salat Jumat belum pernah di selenggarakan karena hanya digunakan untuk mendirikan salat wajib 5 waktu secara berjamaah. Pengurus musala Al Anwar telah berencana mendirikan kegiatan salat Jumat di musala tersebut. Permasalahan yang ada adalah kuranya tempat yang bisa digunakan untuk menampung jamaah. Kegiatan pengabdian yang telah dilaksanakan memberika solusi dengan menambah bangunan atap pada halaman musala. Dengan penambahan konstruksi bangunan atap pada halaman musala tersebut dapat meningkatkan kapasitas penampungan jamaah dan juga dapat digunakan untuk menunjang kegiatan lainnya.
\end{abstract}

Kata Kunci: Konstruksi Atap, Salat Jumat, Pandemi Covidıg,

\section{Pendahuluan}

Menurut Ayub dkk (1996) masjid berasal dari bahasa arab sajada yang berarti tempat bersujud atau tempat menyembah Allah swt. Nurul Jannah (2016) menyatakan bahwa masjid juga merupakan tempat orang berkumpul dan melaksanakan salat secara berjama'ah dengan tujuan meningkatkan solidaritas dan silaturahmi di kalangan kaum muslimin, dan di masjid pulalah tempat terbaik untuk melangsungkan salat Jum'at. Hanafie dan Syahruddin (1998) menyatakan bahwa beberapa fungsi dari masjid/musala adalah digunakan untuk aktivitas ibadah, sosial kemasyarakatan, pendidikan, dan politik.

Salah satu tempat ibadah yang digunakan untuk kegiatan pembinaan umat dan sosial kemasyarakatan asalah Musala Al Anwar yang terletak di Dukuh Sawahan, Kelurahan Pendowoharjo, Kecamatan Sewon, Kabupaten Bantul DIY. Musala Al Anwar telah digunakan untuk kegiatan belajar agama dan salat berjamaah 5 waktu. Untuk meningkatkan fungsi musala dalam aspek ibadah dan kegiatan sosial kemasyarakatan, perlu dilakukan kelengkapan sebagai penunjang aktivitias di musala.

Saat ini masyarakat Dukuh Sawahan belum mendirikan jamaah salat Jumat di dukuh tersebut. Salat Jumat masih menumpang di Masjid Nurul Murtaja Dukuh Sakolan. Akibat pandemi Covid-19, maka masjid Al Iman menerapkan protokol kesehatan dengan jarak antar saf jamaah minim 1 meter sehingga masjid tidak mampu menampung seluruh jamaah pada kegiatan salat Jumat. Atas alasan tersebut Musala Al Anwar di Dukuh Sawahan akan dikembangkan menjadi masjid dan digunakan untuk mendirikan kegiatan salat Jumat sesuai protokoler kesehatan Covid-19. Hal inilah yang melatarbelakangi kegiatan pengabdian masyarakat dengan mitra takmir musala Al Anwar yang bertujuan untuk meningkatkan daya tampung jamaah musala untuk mengadakan kegiatan salat Jumat sesuai sesuai anjuran pemerintah terhadap protokoler kesehatan covid-19. Upaya yang dilakukan adalah dengan pemasangan atap pada halaman musala $\mathrm{Al}$ Anwar sehingga bisa digunakan untuk menunjang seluruh kegiatan keagamaan terutama rencana pelaksanaan ibadah salat Jumat.

Metode Pelaksanaan 
Metode pelaksanaan kegiatan pengabdian masyarakat dilaksanakan dengan pemasangan atap baja ringan di halaman musala Al Anwar. Pelaksanaan dimulai dengan pemasangan balok baja ringan sebagai penopang seperti pada Gambar 1. Setelah pemasangan rangka selesai, dilanjutkan dengan pemasangan baja penutup atap seperti pada Gambar 2.

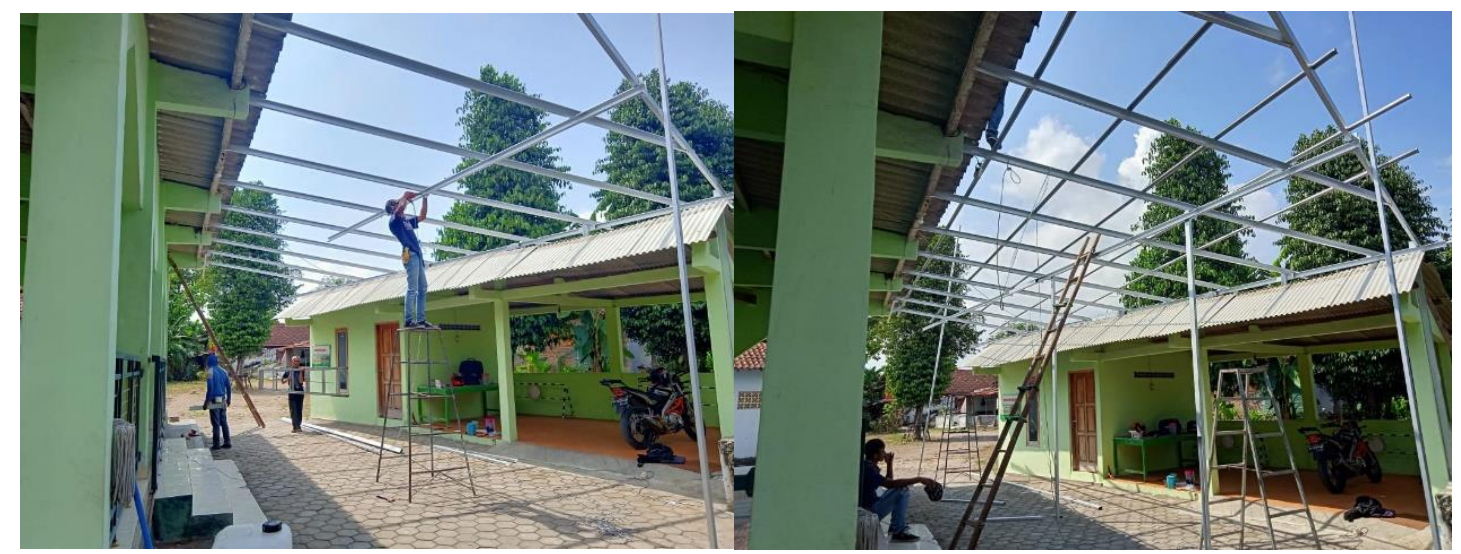

Gambar 1. Pemasangan rangka atap baja ringan

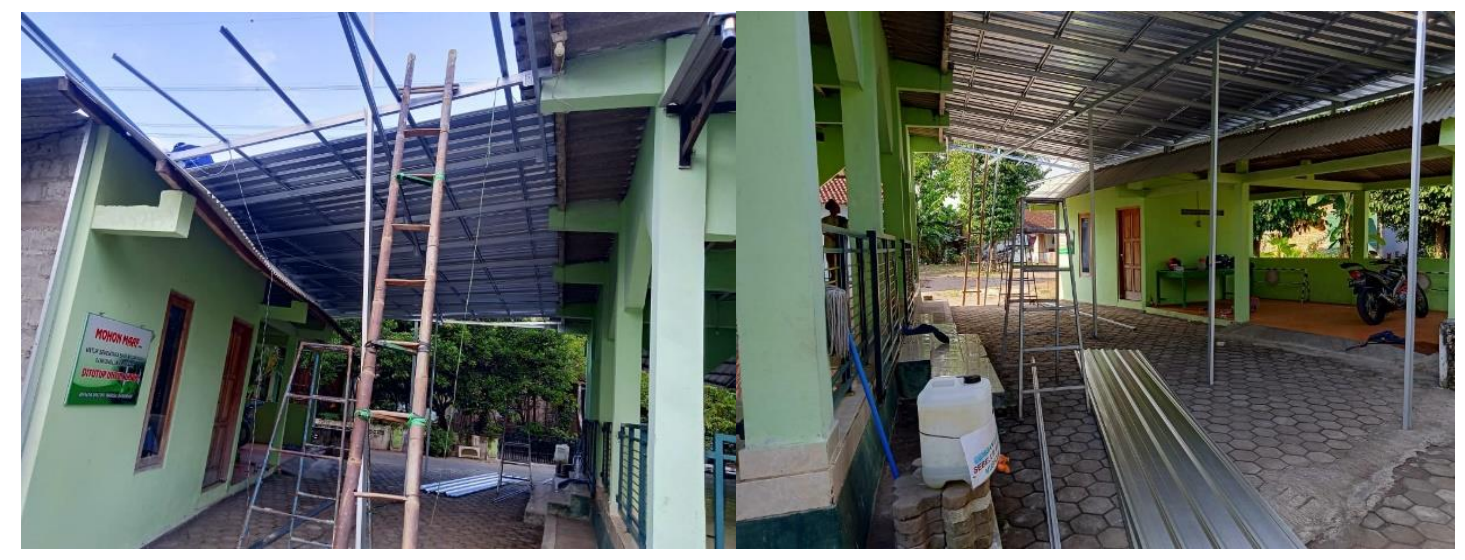

Gambar 2. Pemasangan elemen penutup atap baja ringan

\section{Hasil dan Pembahasan}

Pelaksanaan program pengabdian masyarakat pada skema PKM di Musala Al Awar sangat bermafaat bagi kemaslahatan umat. Pemasangan atap pada halaman Musala Al Anwar yang telah dilaksanakan dapat meningkatkan kenyamanan jamah dan menunjang kegiatan keagamaan yang diselenggarakan. Kegiatan keagamaan yang telah memanfaatkan hasil kegiatan pengabdian masyarakat adalah pelaksanaan qurban di hari raya Idul Adha yang bertepatan pada hari Jumat tanggal 31 Juli 2020 seperti pada Gambar 3. Selain kegiatan penyembelihan qurban di hari raya Idul Adha, hasil pengabdian masyarakat juga telah dimanfaatkan untuk menunjang kegiatan peringatan maulid Nabi Muhammad SAW yang dilaksanakan pada hari Rabu tanggal 28 Oktober 2020 seperti pada Gambar 4 - Gambar 6. 


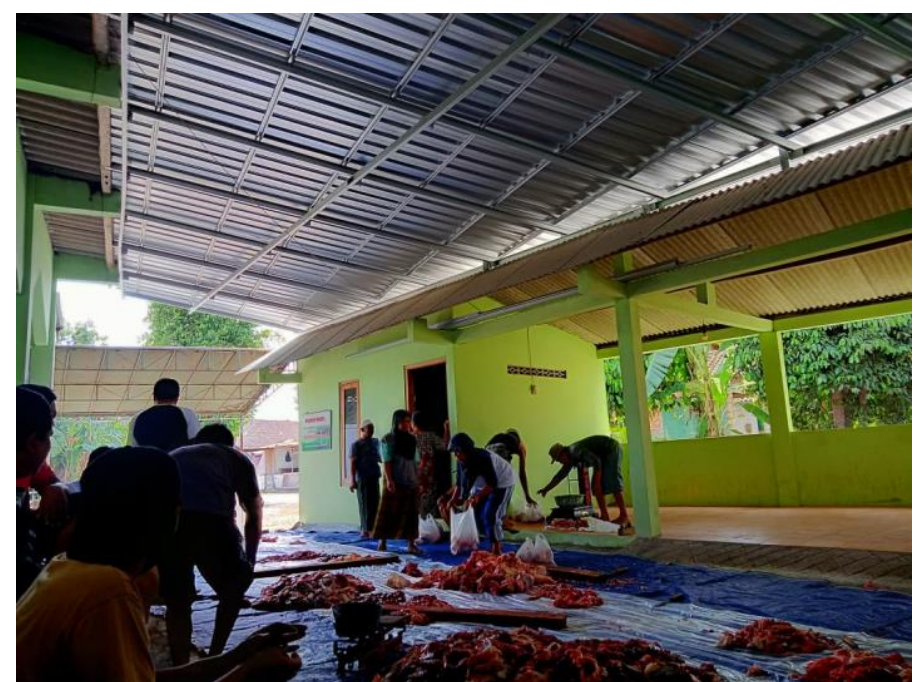

Gambar 3. Pemanfaatan halaman musala Al Anwar untuk kegiatan qurban pada hari raya Idul Adha Jumat 31 Juli 2020

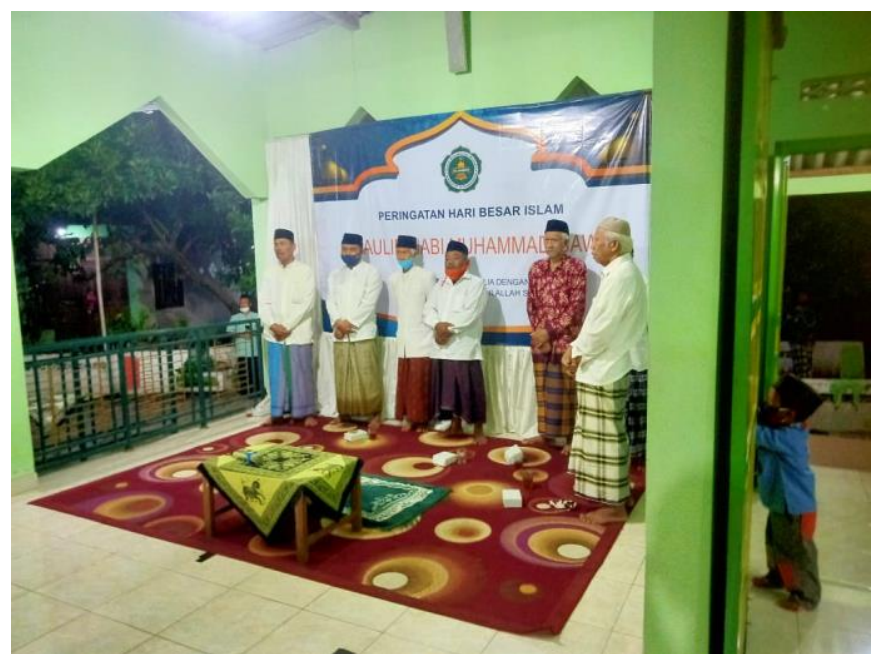

Gambar 4. Panggung Pembicara Utama Pengajian Peringatan Maulid Nabi SAW di Musala Al Anwar tanggal 28 Oktober 2020 yang berlokasi di serambi musala.

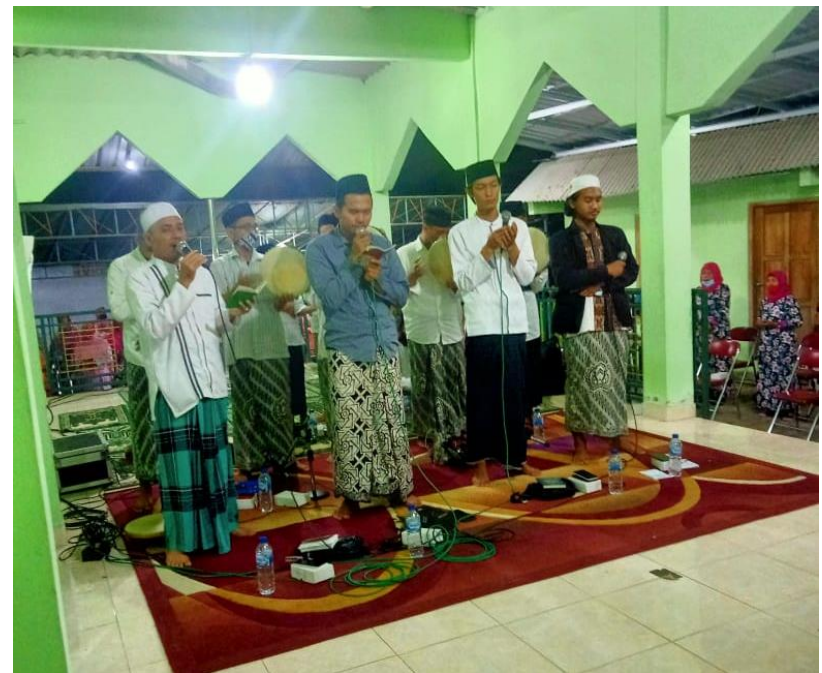

Gambar 5. Panggung Pengiring Hadroh Pembacaan Salawat pada Pengajian Peringatan Maulid Nabi SAW di Musala Al Anwar tanggal 28 Oktober 2020 yang berlokasi di serambi musala. 


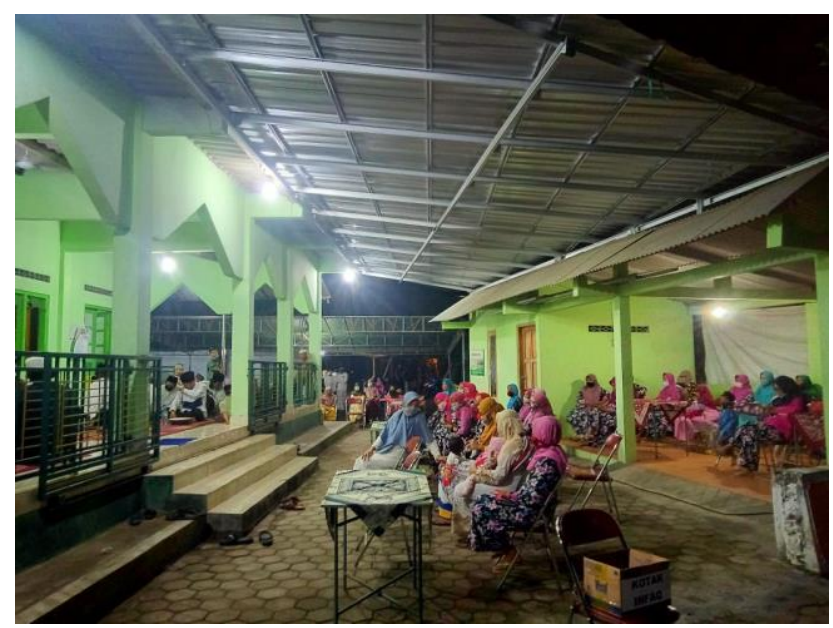

Gambar 6. Halaman Musala Al Anwar digunakan untuk pengajian peringatan maulid Nabi SAW pada tanggal 28 Oktober 2020.

\section{Simpulan}

Dari hasil analisis dapat disimpulkan bahwa kegiatan pengabdian di musala Al Anwar dapat meningkatan kenyamanan dalam beribadah dan menunjang kegiatan keagamaan. Pelaksanaan kegiatan pengabdian berjalan dengan lancar dan mendapatkan antusias dari seluruh masyarakat dan jamaah Musala Al Anwar.

\section{Ucapan Terima Kasih}

Penulis mengucapkan terima kasih yang sebesar besarnya kepada Universitas Muhammadiyah Yogyakarta yang telah memberikan pendanaan melalui LP3M UMY pada skema Program Kemitraan Masyarakat (PKM). Ucapan terima kasih juga penulis sampaikan kepada takmir musala Al Anwar dan masyarakat Dukuh Sawahan yang telah bekerja sama dan mendukung adanya kegiatan PKM.

\section{Daftar Pustaka}

Ayub.E. Mohammad, Muhsin, Mardjoned.Ramlan. (1996). manajemen masjid Jakarta: Gema Insani Press.

Hanafie, Syahruddin, (1988) Mimbar Masjid, Pedoman untuk para khatib dan pengurus masjid. (Jakarta: Haji Masagung), hlm. 348.

Nur Jannah (2016) Revitalisasi Masjid di Era Modern : Jurnal Analytica Islamica, Vol. 5, No. $1,: 125-148$. 